\title{
From the Atlantic to the Urals? Italian and French communism and the question of Europe, 1956-1973
}

\author{
Maud BRACKE
}

The decade of the "long 1960s" was crucial in shaping and changing the attitudes of the Italian and French Left with regard to European integration. This article deals with the positions taken by the Italian and to a lesser extent the French communist party (Partito comunista italiano, PCI, and Parti communiste français, PCF) vis-à-vis the EEC and the idea of a unified Europe. A striking contrast distinguishes the two cases in this regard. The two parties had since the start of the Cold War taken on strongly negative positions vis-à-vis the EEC and its institutions, on the basis largely of the Soviet analysis of and Soviet propaganda on the nature of European integration. In this analysis, the EEC was understood as a product of the Cold War and of American dominance over Western Europe, intended to provide the economic and political framework for the re-armament of West Germany, as well as to undermine the Soviet Union and the communist governments in Eastern Europe. Furthermore, the anti-EEC stance of PCI and PCF was based on a social argument - European integration was seen as an expression of the concentration of capital - and, in the case of the PCF especially, an argument relating to the loss of national sovereignty.

During the 1960s the PCI gradually shifted towards a more positive stance on the EEC, an evolution hallmarked by the entry of a PCI delegation in the European parliament in 1969. By the early 1970s, the party came to see the EEC as a potential vehicle for social and political change in Europe. The PCF, by contrast, continued throughout the 1960s to oppose any form of West European integration. It was only in the early 1970s, in the context of its continued domestic alliance with the socialist party, continued problematic relations with the Soviet communist party, and under the influence of the PCI, that the French communists came to accept, although never welcome, West European integration. The PCF's gradual acceptance of the EEC was always more tactical than it was in the case of the PCI, and signified a far less fundamental change in its international outlook and strategy.

In this article I set out to demonstrate how the two parties' positions with regard to Europe can be understood as resulting from the specific impacts of European détente on domestic politics in the two countries. Doing so, I aim to contribute to the existing literature, not only by using primary document from the PCI, PCF and SED (Sozialistische Einheitspartei Deutschlands) archives, but also by refining our understanding of the impact of 1960s European détente on West European communism. ${ }^{1}$ The ambivalent impact of European détente on West European communism has not sufficiently been understood in the mass of literature on Eurocommunism in the 1960s-1970s. Much of this literature has in an unproblematic way assumed the positive impact of détente on West European 
communism and specifically the PCI, and has, accordingly, failed to note the contradictions in the PCI's views on Europe and détente in this period. ${ }^{2}$

The only recent, archive-based monograph on the PCI and the question of Europe in the 1960s, L'Europa degli altri by Mauro Maggiorani, usefully emphasises the centrality of détente, as well as offering the first comprehensive account of the PCI's shifting positions. ${ }^{3}$ However, when the PCI case is not compared to another one such as the PCF, the specificity of the Italian situation, both in terms of the domestic political situation and in terms of the country's position in the Cold War, cannot come out clearly. It will become clear here through the comparison that the parting of the PCI's and PCF's European ways in the 1960s reflects more than anything else the different positions held by Italy and France in European and global Cold War politics, as well as the ambivalent impacts of détente on domestic politics in Western Europe.

\section{Détente in Europe and Italy}

There was in the early 1960s a remarkable symmetry between the rise of détente on the global and European level, and developments in Italian domestic politics which allowed the PCI to partially escape its political isolation of the 1950s. It is this set of circumstances that convinced a generation of PCI leaders that European integration had the potential of providing a context for the kind of European détente which would allow for the PCI's move towards governmental power. In this perspective, European integration and European détente would create the circumstances in which Italy and other West European states would become more

1. I have used the following archive collections: Archivio del PCI (APCI), Istituto Gramsci, Rome; Funds: Direzione (full minutes of the meetings of the Direzione), Comitato centrale ("CC", full minutes of the Central Committee meetings), and Fondo Berlinguer, which includes the personal papers of Enrico Berlinguer (study documents, reports of meetings, correspondance); Archives Parti communiste francais (APCF), Paris; collection accessible at the time of my consultation in 2001/02 (but meanwhile closed): Bureau politique ("BP", agendas and conclusions of the meetings), Comité central ("CC", agendas and conclusions of the meetings), Secrétariat (agendas and conclusions of the meetings), Fonds Waldeck Rochet - Provenance Secrétariat Marchais (personal papers, transferred to Marchais' office after 1968, including some reports of meetings and conferences, preparations of letters and speeches, correspondences); Ministerium für Auswärtige Angelegenheiten (MfAA), Berlin: Politisches Archiv; Zentrales Parteiarchiv SED (ZPA-SED), Stiftung Archiv der Parteien und Massenorganisationen der DDR im Bundesarchiv (SAPMDB), Berlin: Buro W. Ulbricht, Buro H. Axen.

2. See for example H. TIMMERMANN, Democratic socialists, Eurocommunists and the West, in: W. GRIFFITH (ed.), The European Left: Italy, France and Spain, Lexington Books, Lexington, 1979. A still very valuable attempt at developing a more sophisticated view on détente and Eurocommunism is presented in the various contributions to R. TOKES (ed.), Eurocommunism and détente, Martin Robertson, Oxford, 1978, which, however, are not based on unpublished primary sources.

3. M. MAGGIORANI, L'Europa degli altri. Comunisti italiani e integrazione europea 1957-1969. Carocci, Rome, 1998. 
autonomous from the United States, a process through which, ultimately, the Cold War division of the continent would be "overcome" and West European countries would be free to choose socialism.

The Berlin crisis of 1961 and the Cuban missile crisis of 1962 led to the first onset of détente between the superpowers. In Europe, these crises on the short term gave way to the establishment of what Marc Trachtenberg has referred to as the European political Cold War system. ${ }^{4}$ The system was based on respect for the status quo (including the so-called territorial status quo, the 1945 frontiers, as well as the informal superpower division of spheres of influence), West Germany's non-access to nuclear weapons, and continued intense US presence in the country. In Western Europe, there was in the early 1960s a shift in public opinion with regard to Cold War matters: as superpower acceptance of the status quo in Europe had become evident, public opinion started to feel less directly threatened by the Soviet Union. ${ }^{5}$ This led to a crisis in anti-communist politics which had served as a source of legitimation and public support for governments since the start of the Cold War in countries like Italy. It was in this sense that that early superpower détente, while stabilising relations between the superpowers, acutely destabilised relations within the blocks as well as the social and political order within states, based since 1948 on the Cold War consensus. ${ }^{6}$ Within NATO, the major challenge came from French president Charles de Gaulle's policy of rapprochement to the East European and Soviet regimes. Also early Ostpolitik between 1966 and 1968, although in a less acute way, destabilised the balance of power within the Western alliance. This coincided with a severe crisis of Soviet hegemony in Eastern Europe, provoked notably by Nicolae Ceaucescu in Romania, and relating to a number of disagreements over military and strategy and nuclear proliferation as well as economic integration. ${ }^{7}$

The crisis of the Cold War consensus and the de-legitimation of anti-communist politics were translated in the Italian political context into a crisis in the Democrazia cristiana (DC), the dominant government party since 1948. Having lost its majority in 1953, around 1960 the DC found it increasingly difficult to build a coalition government without the socialist party PSI (Partito socialista italiano). The PSI became not only unavoidable, it also became acceptable as a government partner, especially given its break with its earlier neutralism in the Cold War and its distancing from the Soviet Union and the PCI starting in 1956. Despite strong opposition within the DC against a coalition with the socialists, Aldo Moro's

4. M. TRACHTENBERG, A constructed peace. The making of the European settlement, 1945-1963, Princeton UP, Princeton, 1999.

5. A similar point in E. CONZE, "Cold War crises and Public Opinion". West European public opinion and the Berlin Wall", in: W. LOTH (ed.), Europe, Cold War and Coexistence 1955-1965, Frank Cass, London, 2004, pp.90-91.

6. J. SURI, Power and Protest. Global Revolution and the Rise of Détente, Harvard University Press, Harvard, 2003, pp.41-43.

7. H. CARRERE D'ENCAUSSE, Le grand frère. L'Union soviétique et l'Europe soviétique, Fayard, Paris, 1983, chapter 4. 
strategy of "opening to the Left" became dominant in the DC in the early 1960s. In 1963, the PSI entered into the first Moro government, and centre-left coalitions were to govern Italy up to $1969 .{ }^{8}$

It was early détente that made the "opening to the Left" possible, in that it took away the main ideological argument against socialist government participation. ${ }^{9}$ Also in terms of its policy contents, the centre-left's reformist strategy was quintessentially one of 1960 s détente, and its contradictions can be seen as reflecting the ambivalent nature of 1960s détente. The contradictions of the centro-sinistra were to do on one level with its anti-communist nature, and the question whether the centre-left was aimed at isolating the PCI. Another contradiction was to do with the fact that the centro-sinistra was based on a shaky coalition between, on the one hand, those in the PSI and on the left of the DC who aimed at profound economic and social reform as well as a reconfiguration of the political landscape and, on the other hand, the majority in the DC which aimed at preventing fundamental social and economic reform and wished to maintain the DC's political supremacy. Such avoidance of structural social and economic reform was indeed possible between 1963 and 1966, through the - extensive rather than intensive - economic growth created by Italy's "economic miracle". ${ }^{10}$ The coming of the centre-left, thus, presented the PCI with a contradictory challenge, not unlike the challenge posed to it by European détente. This is why the issue of the centre-left and how to respond to it provoked intense debate in the PCI, notably between the so-called right, headed by Giorgio Amendola and Giorgio Napolitano, who were in favour of a classic communist-socialist rapprochement as a way to avoid PCI isolation, and the so-called left, headed by Pietro Ingrao, who started to think in terms of a social rather than a political alliance aimed at shaking up Italy's party system. ${ }^{11}$

8. On the coming of the centre-left government see: P.L. BALLINI, S. GUERRIERI, A. VARSORI (eds.), Le istituzioni repubblicane dal centrismo al centro-sinistra 1953-1968, Carocci, Rome, 2006; S. COLARIZI, Storia politica della repubblica 1943-2006, Laterza, Rome-Bari, 2007, chapter 3; R. GUALTIERI, L'Italia dal 1943 al 1992. PCI e DC nella storia della Repubblica, Carocci, Rome, 2006, pp.143-151.

9. R. GUALTIERI, op.cit., pp.145-146. In addition, the centro-sinistra had crucially become possible because in 1963 the Kennedy administration turned to support it. One reason for this was the expectation that the PSI in government would oppose an Italian nuclear programme. L. NUTI, Gli Stati uniti e l'apertura a sinistra. Importanza e limiti della presenza americana in Italia, Laterza, Rome-Bari, 1999, pp.500-517.

10. R. GUALTIERI, op.cit., pp.153-154.

11. On the centro-sinistra debate in the PCI see P. GINSBORG, Storia d'Italia dal dopoguerra a oggi. Societá politica 1943-1988, Einaudi, Turin, 1989, pp.397-398. 


\section{The PCI's détente, the PCI's Europe}

An important strand of opinion in the PCI leadership, mostly of the right current, started to emphasise the potential benefits of European détente to the PCI and its domestic strategy and political position. Already in 1962, the PCI had devoted much of its $10^{\text {th }}$ national congress to issues of peaceful coexistence and European détente. ${ }^{12}$ The choice to place peaceful coexistence at the centre of attention was still a sign of obedience to the Soviet Union, motivated by the need to demonstrate support to Moscow in its dispute with Maoist China over peaceful coexistence. Yet, if strictly speaking the 1962 Congress texts did not depart from the Soviet line, the points that were emphasised gave proof of a growing awareness of the PCI's own, specific interests in peaceful coexistence and détente, grounded in its domestic political experience and increasingly disconnected from Soviet foreign policy interests. The party's view on peaceful coexistence and détente was one in which improved East-West relations would be accompanied by the loosening of cohesiveness and hierarchies within the two blocks. This was evident from the emphasised call for the "withdrawal of all foreign bases across the European continent". ${ }^{13}$ Such a statement was in contradiction with Washington's détente policies but it also went counter to Soviet interests in détente. Also the party's new insistence here on "the positive view on the role played by non-aligned states such as Yugoslavia" illustrated its own particular view on what détente in Europe should be: a way to break through the division of the continent and end superpower domination over it.

There was a close and crucial connection between the PCI's emerging European strategy, and the development of its ideas on détente and peaceful coexistence. ${ }^{14}$ While the thesis of the EEC in its origins being a product of the Cold War was maintained, the belief grew that Europe had qualitatively changed, and that a "third force" Europe, increasingly autonomous from the United States, could be turned into an instrument of détente as well as domestic social and political change. Europe, in its continental scope, would be able to contribute to "the overcoming of the blocks" globally. A strategy similar to the party's domestic "long march through the institutions" was to be developed on the EEC level: a broad mobilisation behind, in a first instance, "general-democratic and anti-monopolistic objectives". This meant combating the influence of monopoly capitalism and democratising the EEC's institutions. ${ }^{15}$

12. The resolutions of the $10^{\text {th }}$ national congress: COMITATO CENTRALE DEL PCI, Documenti politici dal X al XI Congresso, Editori riuniti, Rome, 1963, pp.122-156.

13. D. SASSOON, The Strategy of the Italian Communist Party. From the Resistance to the Historic Compromise, Pinter, London, 1981, pp.209-211 (emphasis added - MB).

14. For a similar view see M. MAGGIORANI, op.cit., passim.

15. The theme of democratisation was linked to the question of the PCI's inclusion in the Italian delegation to the Strasbourg parliament, and the PCI leaders were to some extent supported by the PSI. M. MAGGIORANI, op.cit., pp.232-239. 
Within the party leadership a number of individuals developed revised interpretations on the political significance of European integration, and more optimistic views on the potential for social change in (Western) Europe. Important here were especially Amendola and Napolitano. They were influenced by two organisations linked to the PCI: the left-wing trade union Confederazione generale italiana del lavoro (CGIL), and the research centre Istituto Gramsci. At the (Soviet-dominated) World Federation of Trade Unions (WFTU) meetings of 1961 in Moscow and 1962 in Budapest, the CGIL defended its new, more positive positions regarding Europe, arguing that the EEC had become an "objective necessity", which could lead to the improvement of the living conditions of the Italian workers. The Gramsci Institute convened in 1965 an international conference on "Tendencies of European capitalism", which marked a break-through in terms of economic analysis of the EEC. CGIL leader Bruno Trentin argued that European economic integration had led to an increase of the real wages of Italian workers; an affirmation which clearly went counter to the heavily biased opinions expressed on this occasion by the Soviet delegation. In 1965 the CGIL established with the French communist trade union CGT a permanent "liaison office" in Brussels, and in 1969 it sent a representation to the EEC's Social and Economic Committee. Influenced by the discussions in the CGIL and the Istituto Gramsci, the PCI in March 1966 established a "Study Centre for Economic Policy" (CESPE), which equally developed more positive analyses of European economic developments. ${ }^{16}$

This "Europeanism" of part of the PCI leadership was, and would always remain, linked to their focus on a parliamentary strategy, based on domestic and international alliances with social-democratic and socialist parties. ${ }^{17}$ The pro-European position would indeed on the longer term prove to be part and parcel of the social-democratisation of the party. The deep contradictions inherent in this line, notably the party's, and specifically Amendola's continued adherence to and limited criticism of the Soviet-dominated communist world, were not debated in any fundamental way until the invasion of Czechoslovakia in 1968.

It was in the context of the crisis of the EEC in 1963-1965 that majority opinion within the PCI leadership shifted in favour of European integration. The crisis of the EEC and the Gaullist challenge were seen as proof of the collapse of the Atlanticist consensus and the erosion of American hegemony in the Western world. The PCI was particularly attracted to the Gaullist concepts of Europe "from the Atlantic to the Urals" and l'Europe des Patries, with the potential of countering

16. Ibid., pp.251-252.

17. See in particular Napolitano's memoirs, which present a longer-term interpretation of the PCI's development towards a social-democratic party, and the importance in this regard of its European contacts (with, for example, the German SPD and the French socialists). G. NAPOLITANO, Dal PCI al socialismo europeo. Un'autobiografia politica, Laterza, Rome-Bari, 2005. A similar interpretation is presented in the memoirs by Luciano Barca: L. BARCA, Cronache dall'interno del vertice del Pci, vol.1-3, Rubbettino, Catenzaro, 2005. 
superpower dominance. ${ }^{18}$ The PCI in 1963 supported de Gaulle's veto against UK entry into the EEC for reasons of fear of increasing US influence. It welcomed his verbal assault on the Bretton Woods system in 1965 as a sign of the deepening inner contradictions of capitalism. Further, it interpreted de Gaulle's withdrawal of French troops from NATO's integrated military command in the following year as closely connected to this vision of a new, strong Europe "between the blocks". ${ }^{19}$

The PCI perceived the défi francais as not just a French matter, but as the most radical expression of the crisis of the Cold War consensus. It was in this sense enthusiastic also about by the new foreign policy activism displayed by the Italian government around 1965-67. The centre-left government showed interest in improving its (economic, cultural, political) relations with the communist regimes. In 1966 Soviet foreign minister Andrei Gromyko visited Rome and met with Foreign minister Amintore Fanfani, and the following year Chairman of the Supreme Soviet Nikolai Podgorny did the same. Podgorny's visit marked the high point in this evolution, as the two Foreign ministers signed a document calling for the need for a European conference on security. Fanfani increasingly put emphasis on the issue of pan-European co-operation and security. ${ }^{20}$ Party leader Luigi Longo saw Italy now as "a protagonist of a new vision for Europe" and attempted to push the centre-left's foreign policy even further Eastward. ${ }^{21}$

At the 1966 national Congress held in Rome, the party's new European policy was laid out in the following way: (1) the establishment of a denuclearised zone in central Europe, (2) the acceptance of the 1945 frontiers, and thus the acceptance of the sovereignty of the GDR, (3) no West German re-armament, and (4) the signing of a pact of non-aggression between NATO and the Warsaw Treaty Organisation. PCI texts in this period stressed that integration should not be limited to the "small Europe" of the six, but rather should encompass the entire continent. The expectation was that European integration could have positive effects on the domestic political situations in Southern Europe (Spain, Portugal, Greece), as well as on the East European communist regimes. The strong sense of the interdependence of Eastern and Western Europe was probably the most innovative and significant element of the PCI's new views on Europe and gave proof of the fact that a supranational political vision came to be widespread in Italian politics.

Yet it was at the same time in its approach to Eastern Europe that the contradictions of the PCI's new vision on Europe were most pronounced. The "overcoming of the blocks" in theory implied the undermining of Soviet dominance over the Eastern part of the continent. The PCI did, around the mid-1960s, advocate the autonomy of the communist parties in the East. However,

18. This in contrast to the PSI, which critiqued the PCI's blunt ideological agnosticism in its support for the conservative French president. M. MAGGIORANI, op.cit., p.211.

19. More detail on the French challenge to the EEC and NATO in 1963-1965 in N.P. LUDLOW, The European Community and the Crises of the 1960s. Negotiating the Gaullist challenge, Routledge, London, 2006.

20. M. MAGGIORANI, op.cit., p.248.

21. Ibid., p.244. 
it never went as far as to unambiguously argue for the end of Soviet domination in Eastern Europe and much remained unclear on this point. ${ }^{22}$ It was furthermore never specified how this Europe "from the Atlantic to the Urals" would relate to the Soviet Union - which gave the PCI's European vision the same limitations as the Gaullist one. Ironically, it were those in the leadership, like Amendola, who put forward this vision of Europe which left the Soviet question unanswered for, who were at the same time most in favour of maintaining friendly relations with the Soviet Union, as was to become clear during the Czechoslovak crisis of 1968.

Moscow's own positions on the EEC in the mid-1960s were ambivalent. Some in the Kremlin abandoned the harsh anti-EEC positions of the 1950s and took on an "instrumentalist" position with regard to Europe, arguing on the one hand that the crisis of both the EEC and NATO allowed for demilitarisation, and on the other hand that this new Europe was not inherently expansionist like the Atlantic alliance in the 1950s had been. Others, however, including probably Leonid Brezhnev, did see the EEC as a direct threat to Soviet influence in Eastern Europe and argued for increased military spending in this context. A "compromise" in 1966 left the issue largely unresolved, although Brezhnev decided that the EEC needed to be met with both political overtures and militarism. ${ }^{23}$

Well-aware of the widening gap with the Soviet-dominated communist world over the question of Europe, the PCI attempted to have an impact on the discussions in the communist world. It did so at the conference of European communist parties held at Karlovy Vary (Czechoslovakia) in 1967 and during the intense debates preceding it in 1966-1967. The debates at this Conference on European strategy were, to communist standards, exceptionally open and confrontational. During the pre-Conference debates in the party, discussions were focussed, inevitably, on the question of how this new policy would relate to the party's membership of the Soviet-dominated communist world, and how to assess the Soviet concept of détente. Criticism by the radical left within the PCI leadership on Soviet policies with regard to Europe came to the surface. In reaction to the draft resolutions to the Conference, Pietro Ingrao wrote an alternative version, in which he strongly advocated the need for European autonomy in the East-West conflict, and criticised the way peaceful coexistence was carried out by the socialist states. ${ }^{24}$ The call for a system of collective security was linked to the need for unity of an autonomous Europe in its continental scope, which should assume a new role in the global order. In line with Warsaw Pact policies, Ingrao emphasized the need for the recognition of the post-World War Two borders and of

22. Ibid., pp.303-304.

23. J.M. NEWTON, Russia, France and the Idea of Europe, Palgrave Macmillan, New York, 2003, pp.69-77.

24. It is not clear what the reactions to this report in the wider PCI leadership were; according to Carlo Galluzzi, there was no time to propose this alternative version to the Conference, but the amendments proposed by the PCI to the resolutions (see above) were based on this text. APCI, "Berlinguer", 35.3, Nota per la conferenza sulla sicurezza europea. Commenti Pietro Ingrao sul progetto, 18.07.1967. 
the GDR, but it was stressed that this is not a status quo policy. Criticism on the Soviet conception of détente was explicit: "the struggle for peaceful coexistence has in recent years not had the necessary development and impulse, also because it has been understood by part of our forces [i.e. the Soviet-aligned communist world] as a struggle to be carried out essentially by the socialist countries through state and economic initiatives". 25

\section{French communism and French détente}

The PCF's objections against the EEC were based on a double argument: a social argument ("Europe of capital") and an argument relating to national sovereignty. The issue of French national sovereignty had been a central source of domestic political legitimation employed by the PCF. ${ }^{26}$ The PCF had since 1945 promoted itself as the liberator of the French people - a term here understood in its double meaning, national and social. ${ }^{27}$ It had been able to do so in the context of the early Cold War in spite of the evident fact that the party itself was highly dependant on the Soviet Union, because until de Gaulle's return to power in 1958 it was able to present itself as the sole political party in France fighting against US domination. Because the question of sovereignty was so central in the party's identity structure, it was extremely difficult for the party to not see the EEC as a (US-sponsored) vehicle for the undermining of the French nation.

By contrast, to the PCI and to the Italian Left more generally the issue of national sovereignty became less significant as of the 1960s. This was to do with the Left's reactions to the Cold War and international developments more generally. While the matter of national sovereignty was an important one to the Italian Left in the immediate aftermath of the war because it was related to the liberation from Fascism, it bore much less significance as of the 1960s. By then, the Italian Left had come to understand that Italy was not a major actor in international affairs and that its domestic politics had since 1945 been greatly dependant on global Cold War developments. Acknowledging this was politically useful to the Italian Left, as it helped to explain its exclusion from power. In addition, the PCI in the 1960s and 1970s took a rapidly growing interest in developments outside Europe: the "Third World", anti-imperialism, decolonisation. The party started to develop a broader line of thought on imperialism, and on the structural dependency on the United

25. APCI, "Berlinguer", 35.3, Nota per la conferenza sulla sicurezza europea. Commenti Pietro Ingrao sul progetto, 18.07.1967 (my translation - MB).

26. For the use of the concept of sources of legitimation here I refer to De Felice's work on the PCI after World War Two. F. DE FELICE, Doppia lealtá e doppio stato, in: Studi storici, 3(1998), pp.493-563. For my application of this notion to the PCF and its view on sovereignty, see M BRACKE, Which socialism, Whose détente? West European Communism and the Czechoslovak crisis of 1968. CEU Press, Budapest, New York, 2007, pp.21-25.

27. A similar view in M. LAZAR, Le communisme, une passion française. Perrin, Paris, 2005( $2^{\text {nd }}$ ed.), pp.74-77. 
States of not only Third World countries but also countries like Italy. Sovereignty, in this world-view, was not an important political idea because it was not considered a realistic one.

Next to the matter of sovereignty, the PCF's greater reluctance in accepting European integration resulted from the fact that European détente impacted very differently on French domestic politics than it did in Italy. European détente in the mid-1960s, and Gaullist détente specifically, challenged the PCF on the most fundamental level, in terms of its domestic sources of legitimation, its political identity, and its actual domestic strategy. The PCF's objections against any form of détente or peaceful coexistence can be traced back to 1956, when the PCF leadership expressed strong initial disagreement with the Soviet policy of peaceful coexistence with the West. ${ }^{28}$ One indication of the fact that the Thorez leadership was particularly weary of peaceful coexistence was the fact that Pierre Hervé, party journalist, former resistance member and private secretary to Jacques Duclos, was expelled from the party for pointing at the un-revolutionary implications of peaceful coexistence. Hervé had developed an argument on the tension between peaceful coexistence and revolution. It was precisely because Hervé identified the essence of the problem that peaceful coexistence posed to the "orthodox" view on the global class struggle, that his views needed to be tabooed. ${ }^{29}$

While there never was a public debate on this tricky matter, the question whether peaceful coexistence could be beneficial to revolution in the West was a central one in the discussions of the Bureau politique between 1956 and $1961 .^{30} \mathrm{~A}$ majority in the PCF leadership had a basic, almost intuitive sense of the un-revolutionary character of peaceful coexistence. The issue went to the heart of the strategic gap between the Soviet and French communists with regard to the Cold War after 1956: to the SU, the Cold War was to be ended because it damaged the communist regimes and hindered the expansion of socialism, especially to the Third world. To the PCF - and other communists in the West - ending the Cold War was primarily about ending American dominance in the West. The PCF officially accepted Moscow's new line on relations with the West, but purely as a matter of discipline - never out of conviction. Its vision on global politics was always to remain an essentially bipolar one, which equated the global class struggle with Cold War antagonism.

The question of détente became a particularly urgent one to the PCF when around 1965 it felt the actual negative implications of Gaullist détente on its domestic strategies as well as its international alliances. De Gaulle's vision of European integration and of "Europe from the Atlantic to the Urals" defined the terms of the debate on Europe in France in the 1960s. It focused the debate on two questions: American domination over Western Europe and national sovereignty. On

28. F. FEJTO, The French communist party and the Crisis of International Communism, MIT Press, Cambridge, Mass., London, 1967, pp.54-69.

29. F. FEJTO, op.cit., pp. 44-45.

30. F. HINCKER, Le Parti communiste au carrefour. Essai sur 15 ans de son histoire 1965-1981, Albin Michel, Paris, 1982, p.51. 
both issues, de Gaulle succeeded in outbidding the PCF. By obtaining friendly relations with the communist regimes in Eastern Europe and the USSR, and by forcefully re-asserting national sovereignty vis-à-vis the Western alliance, de Gaulle was able to undermine the PCF's main sources of domestic legitimation. In addition, the increasingly friendly relations between Brezhnev and de Gaulle made it clear to the PCF leadership that a fundamental divergence of strategic interests on the European continent had occurred between the CPSU leadership and themselves. This happened on occasion of the French presidential elections of 1965, when the Soviets openly preferred de Gaulle to the Left alliance between the PCF and the newly founded Fédération de la gauche démocratique et socialiste (FGDS). The two parties engaged in an electoral alliance that was based not yet on a common programme but on a joint candidate for the second round of the presidential elections, the socialist François Mitterrand. The latter was considered in Moscow (and by many in the PCF) as pro-Atlantic, and did indeed stand for a foreign policy of close relations with the Atlantic world and the United States. Despite the fact that the Union de la gauche lacked broad support from the apparatuses of either party, it obtained a surprising success at the 1965 presidential elections. ${ }^{31}$ In the midst of the election campaign, Moscow intervened in a manner that was explicitly aimed at undermining the Left alliance. The Pravda published a series of articles in support of de Gaulle's European and détente policy, in meaningful omission of any reference to the Union de la gauche. Equally significantly, the PCF leadership responded in L'Humanité by referring to "the interpretation of domestic French problems by a foreign agency". 32 The harshness of reactions both in Paris and Moscow demonstrates that what was at stake was nothing less than the question of a revolutionary strategy in Europe.

Moscow's strategic interests in Europe went totally counter to those of the FGDS, and this placed the PCF in an impossible position. In other East European capitals, however, there was more interest in discussing matters of European détente with the socialist-communist alliance in France. Notably the Czechoslovak communist party (CPCS) engaged around 1966 in talks with both the French socialists and communists on a "European" solution for Germany, that is to say, a process of improving FRG-GDR relations, initiated and supervised by the European powers, with the aim of evacuating Bonn from US influence. Even the Moscow-loyal East German communist party SED demonstrated at this stage a careful interest in the French Left alliance and, specifically, its views on the German question. Following a number of meetings in 1966-67 between the SED

31. Mitterrand lost to de Gaulle in the second round, but only just, obtaining 45\%. More details on the coming of the Union de la gauche in J. VIGREUX, Waldeck Rochet, une biographie politique, La Dispute, Paris, 2000, pp.234-236; J. KERGOAT, Histoire du Parti socialiste, La Découverte/ Repères, Paris, 1997, pp.144-151.

32. F. FEJTO, op.cit., p.200 (emphasis added-MB). The gravity of the PCF-CPSU fall-out, although it unravelled largely behind the scenes, is evident from the fact, very unusual in the PCF's history, that its political bureau discussed the possibility of protesting against Moscow's intervention in a more direct manner (although it was rejected at this point). Agenda of the BP meeting of APCF, Waldeck Rochet, box 9, file 2. 
and the FGDS, an SED report noted positively that Mitterrand was "personally in favour" of French diplomatic recognition of the GDR (although this was not his party's official position). ${ }^{33}$ These talks were kept secret and therefore had little direct impact. Nonetheless, the fact that they were held does show how the question of European détente provoked cracks in the both the American- and Soviet-dominated alliances and created possibilities for new alliances across the Iron Curtain.

It was only this grave conflict of interests with Moscow that lead the PCF around 1965 to seek alternative alliances in Europe - although this was done carefully and within limits. It was a constant characteristic of the PCF's international politics that it only engaged in alternative international alliances when its relations with the Soviet communist party were under severe pressure. To a significant extent, its more positive perspective on Europe and its rapprochement to the PCI were no more than tactical tools in its stand-off with Moscow over Gaullism and détente. Nonetheless, the PCF did start to revise its positions on the EEC, hereby pressurised by both the FGDS and the PCI. In the mid-1960s relations between the two largest West European communist parties improved significantly, and the PCI leadership succeeded in influencing its French counterpart on a number of issues. A series of meetings took place between the PCI and PCF leadership between 1965 and 1967, some of which took place in the context of the West European "pressure group" that was forming itself in the communist world. The PCI had since 1956 actively sought to establish such a grouping of Western communist parties, as an expression of what it referred to as Polycentrism in the communist world. The aim was double: on the one hand, creating autonomy vis-à-vis Moscow and having, as a group, some impact on discussions in the wider communist world, and on the other hand, providing a forum for the discussion of issues relevant specifically to the West European context and developing practical ways to cooperate. ${ }^{34}$

Despite the PCF's strong initial objections to any type of Polycentrism, the PCI succeeded by 1965 in establishing an informal network of West European communist leaders. The West European communist "cluster" became around 1965 important as a forum in which new ideas on a European strategy for socialism emerged. From discussions on practical co-operation on a European level, the debate shifted to a more substantive one on European integration and the crisis in the EEC. This included discussions of socialist strategy in "late capitalism", reflections on socialism and democracy, broader left alliances, issues of European security, the Cold War and détente, and European integration. At the 1965 Geneva meeting between the two new party leaders Luigi Longo and Waldeck Rochet, the former spoke clearly about prioritising a debate on a "system of collective European security". ${ }^{35}$ The conference of West European communist parties held in

33. MfAA, B24, Bd 606, Die FGDS and die Deutschlandfrage. For more details on these talks, see K. BARTOSEK, Les aveux des archives. Prague-Paris-Prague, 1948-1968, Le Seuil, Paris, 1996, pp.177-180.

34. On Polycentrism see D. SASSOON, op.cit., pp.98-109. 
Brussels in the same year committed to favouring the dissolution of both the Warsaw pact and NATO. One year later, the meeting of Warsaw pact countries in Bucharest adopted the same statement. At the Vienna meeting of 1966 the PCI leadership convinced Rochet, at least in theory, to agreeing to adopt the strategy of "struggle from within" strategy with regard to the EEC. ${ }^{36}$

Nonetheless, the delegations discovered that many disagreements existed on important matters of domestic programme, European and global strategy, and the organisation of the world communist movement. The Italians failed to gather support for a joint statement on the EEC and European integration. ${ }^{37}$ The West European communist grouping was based on a PCI-PCF alliance that was weak because of the two parties' very different perspectives on the domestic and European struggles for socialism and how détente related to this. These two major shortcomings that characterised the West European communist cluster, were also characteristic of Eurocommunism in the 1970. In this sense, the episode discussed here prefigures Eurocommunism but highlights its limits rather than its strengths. ${ }^{38}$

The Karlovy Vary Conference mentioned above brought to the fore the fundamental disagreements that existed between the PCI and PCF - and the disparate effects that European détente was having on the Left in Europe. On the German question, the central and most contentious issue on the agenda, cleavages were complex and, significantly, cut across the East-West division. While Brezhnev in his speech suggested the possibility of a positive response to Ostpolitik, the delegations of East Germany and Poland fiercely rejected this. Among the Western parties, the PCI strongly argued in favour of a positive response to Bonn, which would go beyond rhetoric and would consist of actual co-operation. Other parties such as the PCE and the KPÖ advocated a positive response to Bonn. The PCF, by contrast, remained wary of any positive re-evaluation of West German politics. ${ }^{39}$ The impossibility for West European communists to agree upon détente, Gaullism and Ostpolitik was at the essence of the impossibility to bring about a truly effective West European communist pressure group within the communist world.

35. APCF, "Waldeck Rochet", box 27, folder 4, Notes CC d'avril: points de désaccord avec Longo, (probably Waldeck Rochet), early 1966. It was noted here that there were "positive and negative aspects" to the PCI's policies. With regard to foreign policy "they [the Italian communists - MB] pose fewer questions [than we do-MB] on NATO and other difficult matters".

36. According to what PCF BP member J. Denis told SED leader H. Axen in January 1967. SAPMDB, ZPA-SED, DY/30/IV A 2/20, 457, Vermerk über ein Gesprach des Gen. Hermann Axen mit Gen. Jacques Denis am 30.Januar 1967, p.3.

37. H. TIMMERMAN, Moskau und die Westkommunisten: von Breshnew zu Gorbatschow, in: Berichte des Bundesinstituts für ostwissenschaftliche und internationale Studien, 3(1989).

38. Some of the literature on Eurocommunism has over-estimated the autonomous character of the West European communist cluster in the world communist movement in this phase. (For example K. DEVLIN, The Role of the Non-ruling Communist Parties in Transforming Internationalism, in: L.L. WHETTEN (ed.), The Present State of Communist Internationalism, Lexington, 1983, pp.21-74).

39. APCF, BP, 06.04.1967. 


\section{8-73: European détente controlled}

The Soviet-led invasion of Czechoslovakia in August 1968 demonstrated that what the PCI understood by "dynamic détente" or "détente from below", that is to say the improvement of East-West relations through the loosening of block cohesiveness and the limiting of superpower supremacy, was an illusion. The outcome of the Czechoslovak crisis made it clear that détente would be superpower-led and based on the consolidation of the spheres of influence on the European continent, rather than that it would undermine these. This was the only realistic conclusion that could be drawn from the combined facts of, first, the Soviet need to re-assert control over its sphere of influence in Eastern Europe after a period of challenges to its supremacy, and second, Washington's and NATO's unwillingness to consider the invasion as anything different from an internal Warsaw Pact affair. ${ }^{40}$

The year 1969 marked the start of the era of "controlled détente", in which the superpowers and their European allies aimed at securing and consolidating the benefits of détente in terms of the further stabilisation of the European Cold War system and the non-proliferation of nuclear weapons, whilst avoiding this process to lead to the questioning of Cold War alliances or further destabilisation within the blocks. ${ }^{41}$ This meant putting an end to the instability that early détente had provoked in Europe: challenges to the superpowers' supremacy by their allies, and the questioning of the legitimacy of Cold War ideology and politics in public opinion. The changed meaning of détente involved, firstly, the end of Gaullism. De Gaulle's replacement as president of the French Republic by Georges Pompidou in 1969 signified the end of the urgent challenge to US hegemony in the Western alliance. Although the Pompidou presidency aimed at preserving aspects of the spirit of Gaullist détente and continued to strive towards a unified and politically strong Europe to counterbalance the US, the threat that Gaullist has posed to the US and its role on the old continent had vanished. Despite diplomatic friction between France and the US around 1973, France continued to move towards a more pro-Atlanticist outlook under the subsequent Valéry Giscard d'Estaing presidency. Pan-European détente now included the US - even in French eyes. ${ }^{42}$ Secondly, the consolidation of superpower détente as of 1969 implied a subtle shift in the political meaning of West German Ostpolitik. After 1968, Ostpolitik was carried out by the Willy Brandt government in consultation with the US, and the latter in turn no longer felt it interfered negatively with its own designs for dealing with the Soviet Union and the communist world. ${ }^{43}$

40. On NATO country responses: J. MCGINN, The Politics of Collective Inaction: NATO's response to the Prague Spring, in: Journal of Cold War Studies, 1.3(1999), pp.119-127.

41. See J. SURI, op.cit., for a similar argument on post-1968 détente as a superpower strategy to limit the destabilising effects of early détente on intra-block relations and within societies. R. GUALTIERI, op.cit., pp.165-166, has analysed post-1968 European détente as part the US' " containment through dialogue" strategy.

42. More details in J.M. NEWTON, op.cit., pp.84-88. 
This is, however, not to argue that there were no elements whatsoever of change "from below" in European détente after 1968. Many have argued that European détente continued to feature, up to at least the late 1970s and arguably later, a dimension of bottom-up change, involving non-state rather than state actors, which helped bringing about the end of the Cold War by undermining block cohesion in the East. ${ }^{44}$ In Western Europe, however, there were after 1968 no similar signs of decreased US influence. Atlantic unity was significantly greater in the years following 1969 than it had been in 1962-1968, and it was restored on the basis of US re-assertion vis-à-vis its allies. ${ }^{45}$ US interference in domestic politics in countries like Italy continued to be a reality in the 1970s, although through somewhat different means. ${ }^{46}$ Tragically, from the perspective of West European communism, the crisis of 1968 meant the end of the possibility of radical social and political change in Western Europe through détente.

Similarly, the Soviet vision of détente shifted after 1968. Having forcedly re-asserted its domination over Eastern Europe through the invasion of Czechoslovakia and the subsequent phase of "normalisation" of the People's Democracies, the Brezhnev leadership felt it could engage with the Western powers from a position of relative power. Moscow was fairly successful in the early 1970s in combining its strategic priorities: stability on the European continent and access to West European economies, socialist cohesiveness under its dominance, and controlled political and military détente with the United States. ${ }^{47}$ However, European integration continued to be potentially problematic to Moscow, in as far as it implied an expansionist agenda (vis-à-vis Eastern Europe) and threatened to upset on the status quo on the old continent. ${ }^{48}$

The 1968 invasion of Czechoslovakia caused the PCI, the PCF and most West European communist parties to for the first time in their history explicitly disassociate themselves from Soviet policies. The PCI and PCF did so, however, on the basis of to some extent different arguments, and also the importance of the crisis to the parties' strategies and world-view differed. Most of the PCI leaders interpreted the Prague Spring as an example of a democratic form of socialism, similar to its vision for socialism in Italy and other Western countries. Optimistically, they recognised in the Prague Spring signs of the future of socialism on the European continent. They understood it, in terms of socialist

43. J.W. YOUNG, Cold War Europe 1945-1991, A Political History, Edward Arnold, New York, London, 1996 ( $2^{\text {nd }}$ ed. $)$, p.86.

44. J.M. HAHNIMAKI, Ironies and turning points: détente in perspective, in: O.A. WESTAD (ed.), Reviewing the Cold War. Approaches, interpretations, theory, Frank Cass, London, 2000, pp.326-433.

45. As Pons has noted, the perception of US weakness in the 1970s was, while widespread in Europe at the time, a false one. S. PONS, Berlinguer e la fine del comunismo, Einaudi, Turin, 2006, p.3.

46. More details in O. NJOLSTAD, The Carter Administration and Italy: Keeping the Communists out of Power without Interfering, in: Journal of Cold War Studies, 4.3(2002), pp.56-94.

47. J.M. NEWTON, op.cit., pp.82-84.

48. V. ZUBOK, The Soviet Union and European Integration from Stalin to Gorbachev, in: Journal of European Integration History, 2(1996), pp.85-98, here pp.92-93. 
doctrine, as announcing an era of varied and new forms of democratic socialism. In terms of international relations, they understood it as the result of dynamic détente: the decline of anti-communist politics and American domination in the West, and greater autonomy vis-à-vis Moscow in the East. The invasion, then, shattered all these hopes.

The discussions in the PCI's Direzione in September-October 1968 demonstrate that the party leadership was well aware of the implications of the invasion to the nature of détente in Europe. Publicly, the centrality of détente in the Czechoslovak crisis was acknowledged in the Central Committee statement that was issued a week after the invasion. The party leadership here invoked as motives for its decision to disagree with the invasion the need to "overcome the blocks" and to "liberate Italy from Atlanticism", as well as the need to create a "system of collective security in Europe" ${ }^{49}$ At the first Direzione meeting following the invasion, Achille Occhetto made it clear that "the Soviets confuse internationalism with block politics", while Emanuele Macaluso accused the Soviets of seeking détente on the basis of block consolidation and stated that "the current strategy is objectively working against us". ${ }^{50}$ Yet, it was clear from the outset that the understanding regarding the ambiguous character of détente and the Soviets' different interpretation of it, would not affect the party's aim to work towards a bottom-up type of détente, based on a strong integrated Europe. Amendola in particular made this clear in the days following the invasion, by leading the debate towards focusing on a "dynamic" concept of détente and on the EEC as a means for achieving it. In an October 1968 article in Critica marxista, the party's theoretical journal, he defined the struggle for peaceful coexistence in Europe as "a struggle against the politics of intervention in military, political and economic terms". 51

It was, crucially, Enrico Berlinguer who formulated a response to the invasion of Czechoslovakia and related it to the party's European and détente policies. Berlinguer, vice-secretary at the time and to become the new general secretary in 1972, constructed a new international policy for the party which, while built on deep contradictions particularly in relation to détente, did succeed in introducing a number of changes while avoiding the party's falling apart. His aims included reinforcing the party's understanding of and support for European integration as a strategy for the overcoming of the blocks and of the Cold War. The goal remained dynamic détente, now more explicitly than before defined in contrast to static or top-down détente. The party's engagement in the EEC was significantly reinforced, albeit still critical on issues such as democracy in the EEC institutions.

However, the problem at the heart of Berlinguer's new line lie in the fact that dynamic détente had been compromised by the invasion, to the point that it had become an unrealistic perspective. This was wilfully ignored by the leadership, and

49. CC statement, 29.08.1968, in: COMITATO CENTRALE DEL PCI (ed.), Documenti politici dal XI al XII Congresso, Editori riuniti, Rome, 1969.

50. APCI, Direzione, 020.0926, 23.08.1968.

51. G. AMENDOLA, 25 anni dopo l' internazionale comunista, i: Critica marxista, 4-5(VI), pp 63-87, here p.84. 
a debate on it among the rank and file was discouraged. The precise reasons why the PCI needed to support the EEC and how European integration would create dynamic détente, were after September 1968 not communicated to the rank and file. At the Central Committee meeting of May 1969, Napolitano reiterated the well-known arguments on both the need and the possibility for the West European Left to co-operate and actively work towards a "third way" Europe, independent of the United States and having the potential of weakening Atlanticism. ${ }^{52}$ These, however, had become mere slogans, out of touch with the much cruder realities of international politics in the era of static détente. The leadership's unwillingness to debate its European choice in a more fundamental way was sharply evidenced by the so-called Manifesto affair in the fall of 1969, when a number of leaders of the left within the party were excluded following the publication of an article in the Manifesto paper entitled "Prague is alone". The article strongly denounced the Soviets' static conception of détente and criticised the Berlinguer consensus for its unwillingness to draw the necessary conclusions from this regarding the real rather than desired nature of European détente. ${ }^{53}$

In 1969 the first PCI delegation, headed by Amendola, entered the European parliament. In 1971 Amendola proposed the Eastward enlargement of the EEC. Increasingly, and especially from the early 1970s onwards, "Europe" became one of the core points of reference of the PCI's international outlook and strategy, and a standard element in its rhetoric and political discourses. The shift towards Europe was not only a matter of pragmatism and accepting existing situations, there now was also a teleological, and arguably a utopian dimension in the PCI's European policy. By working inside the European institutional framework, the perspective was, the PCI would contribute to making Western Europe socialist. Concretely, however, the "alternative development of democracy" as a strategy for Europe remained vague. At this point only the immediate, "democratic phase" of the strategy was more or less clear: it focused on the democratisation of the European institutions, for example through the direct election of the European parliament. ${ }^{54}$

Deep tensions existed, and persisted up to the mid-1970s and beyond, between the PCI's pro-European choice and its belonging to the Soviet-dominated communist world. After a phase of open conflict with the USSR in the aftermath of the 1968 invasion, a gradual improvement of relations between the CPSU and the PCI occurred. A new modus vivendi between the two parties came about. To the PCI, a break was impossible for reasons to do with the party's identity, history and unity, but also because it was impossible to claim having an internationalist strategy without belonging to a global movement, however fraught with contradictions. To the Soviets, a break with the PCI was undesirable because the party was after all the most powerful $\mathrm{CP}$ in the West, increasingly successful domestically, and increasingly influential ideologically in the global

52. APCI, Fund Berlinguer, “Comitato centrale maggio 1969”, Unitá, 29.05.1969.

53. On the Manifesto affair, see G. AMYOT, The Italian Communist Party. The Crisis of the Popular Front Strategy, Croon Helm, London, 1981, chapter 6.

54. M. MAGGIORANI, op.cit., pp.212-233. 
anti-imperialist movement. Soviet funding to the PCI was resumed in 1970, and so were the regular bilateral meetings, although the illusion of unproblematic solidarity had forever been lost. ${ }^{55}$

Yet the PCI's vision of an expanding Europe very clearly went counter to Soviet interests; strategically, because it suggested taking Eastern Europe out of the Soviet sphere of influence, and ideologically because it suggested the building of a different, better socialism for this enlarged Europe. Also Berlinguer's abandonment of the two camp theory, which was linked to its pro-European choice, evidently went counter to Soviet interests. ${ }^{56}$ Nonetheless, the Berlinguer leadership succeeded at this stage in avoiding an open clash with Moscow. At a meeting between the CPSU and PCI leaderships in 1973, Berlinguer attempted to make the PCI's European positions acceptable to Moscow, emphasising on the one hand that the PCI still advocated a radically different EEC, which implied the need to revise the treaties, and on the other hand the fact that the EEC no longer merely served US and Atlantic interests. ${ }^{57}$ This was not only a matter of avoiding an open clash with Moscow, it was also an attempt to influence the positions of the communist world. This naive optimism regarding the PCI's own influence characterised also the party's tactics during the Eurocommunist phase of the mid-1970s. ${ }^{58}$

Berlinguer in the 1970s highlighted the neutralist dimension and the vision of Europe "between the blocks" ("A Europe neither anti-American nor anti-Soviet"). ${ }^{59}$ At this stage, the PCI's pro-European stance was still an anti-Atlantic position. In fact, following the invasion of Czechoslovakia, and in the context of left-wing criticism at the Berlinguer line in 1969, the party hardened its stance on NATO.$^{60}$ The slogan "Italy out of NATO, NATO out of Italy" became in the early 1970s once more an important one in PCI propaganda, while it had been downplayed in the years preceding $1968 .{ }^{61}$ However, in the context of improved relations between the European powers and the US in the Atlantic alliance after 1968, there was a clear tension between the party's pro-EEC and anti-NATO stances. This tension, it has been argued, came to be "resolved" between 1973 and 1976, when the party line gradually moved towards accepting US military and political influence in Western Europe and Italy. Berlinguer's explicit acceptance of NATO's presence in Italy in 1976 was welcomed by mainstream political opinion in Italy as the party's belated recognition of the country's security interests. ${ }^{62}$ This

55. See a similar argument on the PCI's inability to break its ties with Moscow over the 1968 crisis, see S. PONS, op.cit., pp.8-11, 51-52, 256.

56. Ibid., p.21.

57. Ibid., pp.26-30.

58. See Urban's comments on the PCI's "evangelical face", in J.B. URBAN, The four faces of Eurocommunism, in: C.F. ELLIOT, C.A LINDEN (eds.), Marxism in the Contemporary West, Westview Press, Boulder, 1980, pp.36-59.

59. S. PONS, op.cit., p.23.

60. G. AMYOT, op.cit., p.179.

61. M. BRACKE, op.cit., pp.279-287.

62. For a discussion of the connections between Berlinguer's pro-European stance and his acceptance of NATO, see: S. PONS, op.cit., pp.257-258. 
move was, however, also the party's final surrendering of any kind of revolutionary vision on a Europe capable of upsetting the Cold War order and superpower hegemony. Moreover, rather than resolved, the tensions within the party's international line were in fact aggravated, as the party still failed to unambiguously reject Soviet-style communism.

In the case of the PCF, the invasion of Czechoslovakia provoked less of a shift in international positions than it did in the case of the Italian communists. The PCF found itself in an impasse, between lack of Soviet support for détente "from below" or even for its domestic strategy of Left unity, and its own inability to move away from its internationalist tradition and identity centred around loyalty to what the Soviet Union represented historically and symbolically. The PCF leadership's post-1968 self-realignment on Soviet positions was nearly complete. While since 1956 sentiments regarding the un-revolutionary character of peaceful coexistence and détente had been widespread in the party, the official line was now one that fully supported the superpower-based vision on European détente, including the Soviets' domination over Eastern Europe. At the Moscow conference in June 1969, the French delegation stated: "As long as there will not be a system of collective security in place, the socialist states have the duty to reinforce their defence and unity". ${ }^{63}$ However, this was not understood in the same way the Soviet leaders understood their own security interests in the early 1970s and did not include the acceptance of friendly relations between East and West. Significantly, the PCF came close to ignoring the Moscow treaty signed by the Soviet Union and the Federal Republic of Germany in 1970, thus implying its lack of enthusiasm for the new European détente. ${ }^{64}$

The party in the 1970s fell back into interpreting the EEC as an expression of American domination in Western Europe - and therefore as a rather insignificant actor in international politics. Admittedly, there were important and visible changes in its attitude vis-à-vis the EEC in this phase, including the sending of its first delegation to the Strasbourg parliament in 1973, and its first participation in the European elections of 1977. Its approach to the EEC was, however, at all times instrumental. The party started to display remarkable pragmatism with regard to the EEC and its institutions. ${ }^{65}$ The argument relating to national sovereignty gained in importance, despite the fact that Brezhnev's doctrine on limited sovereignty of 1968, which the PCF had not explicitly denounced, made it very hard to make strong claims regarding the need for national sovereignty on the European continent. In the context of the Union de la gauche, which in the mid-1970s developed from an electoral to a political alliance based on a common programme, the party's new leader George Marchais and his foreign policy advisor Jacques

63. APCI, "Berlinguer", 81.2, Conferenza PC di Mosca 5-17 giugno 1969. Discussioni, note.

64. The Bureau politique in a very brief statement noted that the treaty "should be considered important". APCF, BP, 13.08.1970.

65. See also A. KRIEGEL, French communism in the Fifth Republic, in: D. BLACKMER, S. TARROW (eds.), Communism in Italy and France, Princeton University Press, Princeton, 1976, pp.69-86, here p.82. 
Kanapa favoured an independent French nuclear force, the force de frappe. This was a suitable way of bridging the gap with the socialists over foreign policy, but did bring the party once more in conflict with Moscow. ${ }^{66}$ This foreign policy was however severely hampered by the fact that it did not allow for a meaningful analysis of the EEC or of Europe as an actor in the Cold War. The PCF indeed spent most of the 1970s ignoring the fact that France's sovereignty was already limited through its membership of the EEC and NATO.

These different approaches to Europe became clear at a PCI-PCF meeting held in June 1970 in Rome. The PCI's position of "change from within" was reinforced: Amendola argued that it was genuinely possible through geographic and political "enlargement" to alter the ideological and political character of the EEC. Jacques Denis of the PCF sharply countered that there was "no objective basis for a [European - MB] third force". The PCF delegation did nonetheless declare itself in favour of an "active presence" in and continued pressure on the EEC institutions, to make them "more democratic and anti-monopolistic". ${ }^{67}$ The differences continued to be pronounced at a conference of West European communist parties held in Brussels in 1974 on the theme of "Europe". The PCI delegation upheld its ambitious yet vague vision of a democratic Europe "which was to realise its role of peace and progress in the world". This contrasted sharply to Marchais' nihilism: "Europe can be the best and the worst". Much of the debate dealt with the practicalities of support among the West European CP's in political and trade union action, and there was little or no substantial discussion on issues related to European integration and the Cold War. ${ }^{68}$

\section{Concluding remarks}

Communist parties such as the French continued up to the end of the Cold War to perceive the global class struggle in terms of the classic East-West confrontation. Relaxation of this confrontation towards the United States or West Germany appeared to them as a retreat from the global class struggle. A Europe "between the blocks" was in this vision unrealistic, if not undesirable. To the PCI, by contrast, the revision of its European policies signified a true, if partial and problematic, transfer of allegiances. The main contradictions inherent to it were to do with the party's continued links with the Soviet Union, and the latter's relation to Europe.

The European debates in the two parties during the long 1960s bear longer-term significance. Firstly, the 1960s episode announces the main limitations and contradictions of 1970s Eurocommunism: the very different views held by the PCI and PCF on "Europe" and its relation to the Cold War, and the PCF's purely

66. G. STREIFF, Jean Kanapa, L'Harmattan, Paris, 2001, pp.547-557.

67. APCI, "Berlinguer", 89, Incontro con delegazione PCF Roma, 25-26.06.70.

68. M. STEINKUHLER, Eurokommunismus in Widerspruch. Analyse und Dokumente, Verlag Wissenschaft und Politik, Köln, 1977, pp.37-48. 
instrumental approach to a European strategy. Furthermore, a direct historical line can be drawn from the PCI's choice to accept and then embrace the EEC in the 1960s-70s, to the policy of quasi-unconditional support for the EU of much of the Italian Left today. This is rooted historically the fact that the impasse of Italian domestic politics in the 1960s was indeed unlocked by the dynamic of early European détente. The Italian Left as a whole has since the 1960s maintained the assumption that European integration would always affect Italian politics positively. Similarly, the PCF's legacy is unmistakable in the European policy of most of the French radical Left today, critical of the EU for reasons to do with both class politics and national sovereignty. While the issue of national sovereignty is today, it can be argued, largely overcome by the facts, the social nature of the EU continues to be a highly pertinent issue. 


\section{Europäische Schriften}

Herausgegeben vom Institut für Europäische Politik

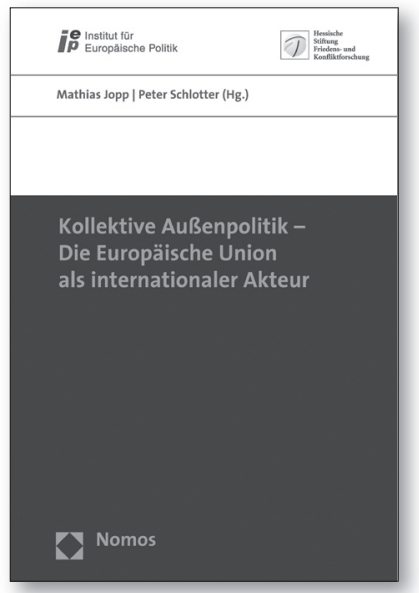

Kollektive Außenpolitik - Die Europäische Union als internationaler Akteur

Herausgegeben von Prof. Dr. Mathias Jopp und Prof. Dr. Peter Schlotter

2007, Band 86, 397 S., brosch., 49,- $€$, ISBN 978-3-8329-2910-7

Die Autorinnen und Autoren zeigen in ihren Studien, dass das verbreitete Bild einer in der Außenpolitik zerstrittenen EU keineswegs durchgängig der Realität entspricht. Zwar kommen in einzelnen Fällen überkommene nationale Reflexe zum Tragen und erschweren ein einheitliches EU-Handeln. Doch zeichnen sich selbst hier Lernfortschritte ab und in vielen anderen Bereichen lassen sich klare Konturen einer langfristig sowie strukturell angelegten EU-Außenpolitik unter Nutzung europäischer „soft power“ feststellen.

\section{Das Erbe des Beitritts}

Europäisierung in Mittel- und Osteuropa Herausgegeben von Amelie Kutter und Vera Trappmann 2006, Band 85, 389 S., brosch., 59,- $€$, ISBN 978-3-8329-1940-5

\section{Deliberation - Ein Zukunftsmodell europäischer Entscheidungsfindung?}

Analyse der Beratungen des Verfassungskonvents 2002-2003 Von Daniel Göler 2006, Band 84, 378 S., brosch., 59,- $€$, ISBN 978-3-8329-1939-9

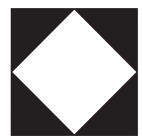

